\title{
Study to Enumerate the Alterations in Gut Bacterial Population of Eudrilus eugeniae Exposed to Sodium Arsenate
}

\author{
Shefali ${ }^{*}$, R.K. Gupta and Dharambir Singh \\ Department of Zoology, CCS Haryana Agricultural University, Hisar-125004, Haryana, India \\ *Corresponding author
}

\section{A B S T R A C T}

\begin{abstract}
The present study was carried out to envisage the impact of heavy metal i.e. arsenic on the gut bacterial population of epigeic earthworm species, E. eugeniae. For this purpose, three different doses $\left(1.04,2.09\right.$ and $3.13 \%$ w/v) of sodium arsenate $\left(\mathrm{Na}_{2} \mathrm{HAsO}_{4} 7 \mathrm{H}_{2} \mathrm{O}\right)$ were used to treat adult earthworms. The gut samples were serially diluted and inoculated in seven distinct media viz. Jensen's media, King's medium B base, Burk's media, Yeast Mannitol Agar media, Vogel- Johnson agar base media, Luria Bertani Broth Miller and Nutrient agar media. Dose dependent decrease in bacterial population was observed in treated worms when compared with control. Significant decrease $64.01 \%, 43.98 \%$, $21.53 \%, 37.50 \%, 44.52 \%, 33.91 \%$ and $26.70 \%$ was observed in gut samples isolated from earthworm's treated with $\mathrm{T} 4$ i.e., $\mathrm{As}(\mathrm{V})(3.13 \%)$ as compared to control cultured on Jensen's media, King's medium B base, Burk's media, Yeast Mannitol Agar media, VogelJohnson agar base media, Luria Bertani Broth Miller and Nutrient agar media respectively. Arsenic poses adverse effect on the health of earthworm as well as alters the microbial population present in gut of earthworms.
\end{abstract}

\section{Introduction}

Soil is a complicated heterogeneous system with the predominance of a solid phase constituted of soil organic matter, minerals, plants, microbes, and faunas (Nannipieri and Badalucco, 2003). Earthworms are accepted to have an association with soil microorganisms ranging from commensalism to speciesspecific mutualism (Sampedro and Whalen, 2007). Without doubt, earthworms are the most vital soil invertebrates in the soil ecosystem as far as biomass and activity being often considered as ecosystem engineers (Esakkiammal and Lakshmibai, 2013).
Additionally, soil contains a large diversity of microorganisms (Torsvik et al., 2002). Associations amongst earthworms and microorganisms appear to be complex. Earthworms are accounted for to have relationship with such free living soil bacteria and constitute the drilosphere (Ismail, 1995; Schrader et al., 2007). In this way, it is realized that microbial biomass and activity are normally improved in the drilosphere, with more prominent numbers of microbial colony forming units (CFUs) in the burrow walls and earthworm casts than in the parent soil (Aira et al., 2007). Earthworms are important drivers of soil biogeochemical processes as they 
change soil physicochemical properties and microbial communities by feeding, burrowing and casting activities and serve a role as useful biological indicators of contamination on account of the consistent relationships between the concentrations of specific contaminants in earthworms and soils(Van Hook, 1974). Soil pollution has recently been drawing in extensive open consideration since the extent of the issue in our soils calls for immediate action (Garbisu and Alkorta, 2003). Among heavy metals $\mathrm{Pb}, \mathrm{Cd}$ and $\mathrm{As}$ are considered potentially important environmental pollutants due to their trends to accumulate on vital organs of humans and animals (Verma et al., 2016). Arsenic (As) can be found in natural soils; however, increments have been detected in soils worldwide as result of anthropogenic activities, particularly through mining (van Coller- Myburgh et al., 2015). In addition to the lethality for mammalians, including humans (Abdul et al., 2015; Alamolhodaei et al., 2015; Joseph et al., 2015), the negative effect of As is notable for the main soil standard invertebrates (Crouau and Moia, 2006; Lee and Kim, 2008; Lock and Janssen, 2002). The impact of heavy metals in soils on earthworms and their bioaccumulation has been the subject of numerous examinations for a long time (e.g. Bouche, 1984; Morgan and Morgan, 1999; Kennette et al., 2002; Ravindran et al., 2015), therefore, heavy metals enter the body of the worm and may cause alterations in gut bacterial population. The aim of the present examination was to investigate the impact of arsenic on the gut bacterial population of earthworms.

\section{Materials and Methods}

Healthy and clitellated adults of E. eugeniae (500-700mg) were collected and exposed to different concentrations of Sodium Arsenate $\left(\mathrm{Na}_{2} \mathrm{HAsO}_{4} 7 \mathrm{H}_{2} \mathrm{O}\right)$ on Whatman no. 1 filter paper coated flat bottom glass vials according to the Table 1. After one hour surface sterilization of earthworm was done by using $70 \%$ ethanol in order to avoid any surrounding bacteria and $0.1 \mathrm{~g}$ of earthworm's gut. Thereafter, the worms were dissected by pinning them in such a way that the ventral side was upside and the clitellum is exposed clearly. Thus, the dissected guts was used for preparation of dilution of $10^{-4}$ and after shaking properly $0.1 \mathrm{ml}$ aliquots of diluted bacterial samples was inoculated on different petri plates having different medium. The plates were incubated in B.O.D for 72 hours in inverted position and thereafter, the colonies were counted carefully and expressed as $\mathrm{CFU}$ x $10^{-4} \mathrm{ml}^{-1}$.

\section{Statistical analysis}

The experiment was laid out in a Completely Randomized Factorial Block Design with three replicates. The critical difference was worked out at 5 per cent (0.05) probability levels using Software 'OPSTAT', developed at the Computer Centre, College of Basic Sciences and Humanities, CCS Haryana Agricultural University, Hisar.

\section{Results and Discussion}

Earthworms have been shown to be microbivorous (Flack and Hartenstein, 1984; Ranganathan and Parthasarathi, 1999). Microorganisms constitute an important nutritional component of the earthworm diet (Edwards and Bohlen, 1996) which helps them in growth and reproduction (Parthasarathi and Ranganathan, 2000). The total viable microbial count observed in the gut of E. eugeniae exposed to arsenic is detailed in Figure 1. The maximum bacterial counts were statistically higher in control sample of Nutrient agar media (176.00土 2.31) followed by Yeast Mannitol Agar media (165.33 \pm 4.48$)$ as compared to those in gut of treated worms. 
Table.1 Description of doses given to the earthworm during experiment

\begin{tabular}{|l|l|l|}
\hline S. No & Treatment & Description \\
\hline 1. & T1 & Control \\
\hline 2. & T2 & Arsenic $1.04 \%$ \\
\hline 3. & T3 & Arsenic $2.09 \%$ \\
\hline 4. & T4 & Arsenic $3.13 \%$ \\
\hline
\end{tabular}

Fig.1 Total bacterial populations $\left(\mathrm{CFU} \times 10^{-4} \mathrm{ml}^{-1)}\right.$ in the gut of E. eugeniae cultured in different nutrient media exposed to different concentrations of arsenic

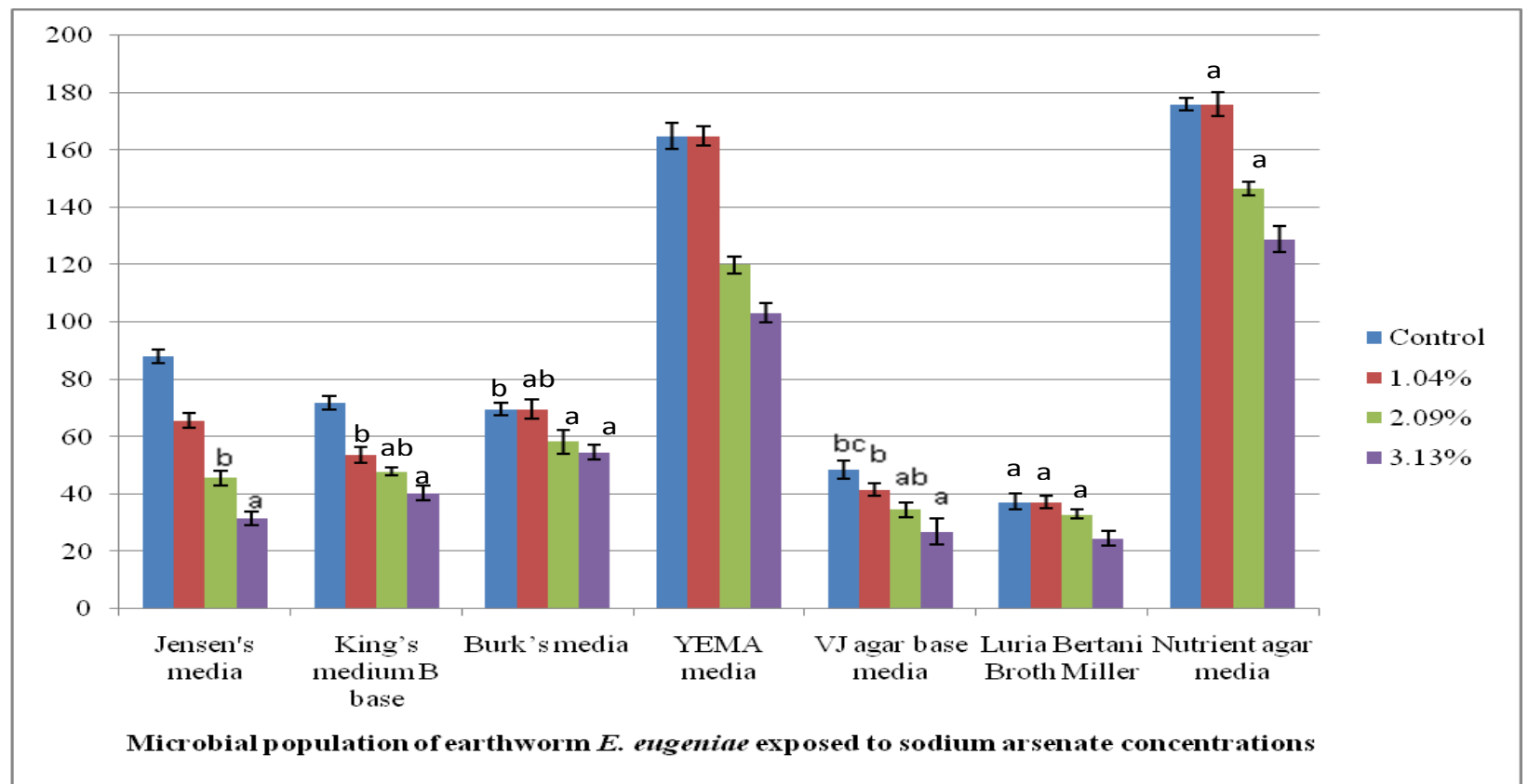

The maximum decrease in the bacterial population was noticed in Jensen's media (64.01\%) followed by Vogel- Johnson agar base media (44.52\%), exposed to $\mathrm{T} 4$ as compared to control. However, when cultured on Luria Bertani Broth Miller, significantly lower viable counts $(37.33 \pm 2.73)$ were observed in gut of worms exposed to T2, T3 and $\mathrm{T} 4$ as compared to each other and control.

Similarly significant reduction in total bacterial count in worms exposed to arsenic was observed in comparison to control when cultured on King's medium B base, Burk's media, Yeast Mannitol Agar media and Nutrient agar media.
Parthasarathi et al., (2007) reported that there is direct correlation between the microbial population and humic acid content in earthworm casts, with the increase in microbial population, there is an increase of microbial activity and humic acid content. Ravindran et al., (2015) stated that the microbial population significantly expanded in the SmF and SSF applied earthworm gut contrasted with earthworms from control, along these lines it is demonstrated that the hydrolysed ANFL (Animal Fleshing) may act as a favorable feed mixture to earthworm $E$. eugeniae. Earthworms are accounted to have relationship with such free living soil microbes and constitute drilosphere. 
Esakkiammal and Lakshmibai (2013) reported that the bacterial population was more in mid gut than foregut and hindgut region and the results demonstrated that the organic substrates used could initiate the proliferation of micro-organisms. However each one of these examinations was confined to one part of earthworm-microbe relationship or proliferation of microbes in gut and casts. They together mineralize and humifies the organic matter. Thus, from the investigation it is inferred that arsenic at higher concentration alters the survival of bacterial communities.

\section{Acknowledgement}

We thank to the authorities of Department of Zoology to make available the facilities and timely help required for carrying out the research program.

\section{References}

Abdul, K.S.M., Jayasinghe, S.S., Chandana, E.P.S., Jayasumana, C. and De Silva, P.M.C.S. 2015.Arsenic and human health effects: a review. Environ Toxicol Phar., 40(3): 828-846.

Aira, M., Fernando, Monroy. and Jorge, Domnguez. 2007. Eisenia fetida (Oligochaeta: Lumbricidae) Modifies the Structure and Physiological Capabilities of Microbial Communities Improving Carbon Mineralization during Vermicomposting of Pig Manure. Micro. Ecol., 54: 662671.

Alamolhodaei, N.S., Shiranim K. and Karimi, G. 2015. Arsenic cardiotoxicity: an overview. Environ Toxicol Phar., 40(3):1005-1014.

Anjali, Verma., Ashok, Ghosh., Mamta, Kumari., Namita, Dhusia. and Nandkishor, More. 2016. Bioremediation potential of Eisenia fetida and microbes for arsenic contaminated soil and water. Int. J. Biol. Res., 1(4):15-21.

Bouche, M. 1984. Ecotoxicologie des lombriciens. 2. Surveillance de la contamination des milieux. Oecologia Applicata., 5: 291-301.

Crouau, Y. and Moia, C. 2006. The relative sensitivity of growth and reproduction in the springtail, Folsomia candida, exposed to xenobiotics in the laboratory: an indicator of soil toxicity. Ecotoxicol Environ Saf., 64(2): 115-21.

Edwards, C. A, and Bohlen, P.J. 1996. Biology and Ecology of earthworms. Chapman and Hall, London.

Esakkiammal, B. and Lakshmibai, L. 2013. Enumeration of bacterial population in the gut region of Eudrilus eugeniae. Int. J. Curr. Microbiol. App. Sci., 2(5): 267270.

Flack, F.M. and R, Hartenstein, 1984. Growth of the earthworm Eisenia fetida on microorganisms and cellulose. Soil Biol. Biochem., 16: 491-495.

Garbisu, C. and Alkorta, I. 2003. Basic concepts on heavy metal soil bioremediation, Eur. J. Min. Proc. \& Environ. Protect, 3: 58-66.

Ismail, S.A. 1995. Earthworms in soil fertility management. In: Thampan PK (ed). Organic Agriculture. pp 77100.

Joseph, T., Dubey, B. and McBean, E.A. 2015 Human health risk assessment from arsenic exposures in Bangladesh. Sci Total Environ, 527-528: 552-560.

Kennette, D., Hendershot, W., Tomlin, A. and Sauve, S. 2002. Uptake of trace metals by the earthworm Lumbricus terrestris L. in urban contaminated soils. Appl. Soil. Ecol., 19: 191-198.

Lee, B.T. and Kim, K.W. 2008. Arsenic accumulation and toxicity in the earthworm Eisenia fetida affected by chloride and phosphate. Environ Toxicol Chem., 27:2488-2495. 
Lock, K. and Janssen, C.R. 2002. Toxicity of Arsenate to the Compost worm Eisenia fetida, the Pot worm Enchytraeus albidus and the Springtail Folsomia candida. Bull Environ Contam Toxicol., 68:760-765.

Morgan, J.E. and Morgan, A.J. 1999. The accumulation of metals $(\mathrm{Cd}, \mathrm{Cu}, \mathrm{Pb}, \mathrm{Zn}$ and $\mathrm{Ca}$ ) by two ecologically contrasting earthworm species (Lumbricus rubellus and Aporrectodea caliginosa): implications for ecotoxicological testing. Appl. Soil. Ecol., 13: 9-20.

Nannipieri, P. and Badalucco, L. 2003. Handbook of processes and modelling in the soil-plant system. Biological processes. In: Benbi DK, Niedere $\mathrm{R}$ (eds) Haworth, Binghamton, N.Y. pp 57-82.

Parthasarathi, K. and L. S. Ranganathan. 2000. Influence of pressmud on the development of the ovary, oogenesis and the neurosecretory cells of the earthworm, Eudrilus eugeniae (Kinberg). African Zool., 35(2): 281286.

Parthasarathi, K., L.S. Ranganathan., V. Anandi and Josef, Zeyer. 2007. Diversity of microflora in the gut and casts of tropical composting earthworms reared on different substrates. $J$. Environ. Biol.., 28(1): 87-97.

Ranganathan, L.S. and K, Parthasarathi. 1999. Precocious development of Lampito mauritii and Eudrilus eugeniae reared in pressmud. Pedobiologia, 43: 904908.

Ranganathan, L.S. and K, Parthasarathi. 2005. Humification of cane sugar mill wastes by Eudrilus eugeniae (Kinberg). J. Ann. Uni., 41: 1-8.

Ravindran, B., S.M, Contreras-Ramos, and G, Sekaran. 2015. Changes in earthworm gut associated enzymes and microbial diversity on the treatment of fermented tannery waste using epigeic earthworm Eudrilus eugeniae. Eco Eng., 74:394401.

Sampedro, L. and Whalen, J.K. 2007. Changes in the fatty acid profiles through the digestive tract of the earthworm Lumbricus terrestris. Appl. Soil. Ecol., 35: 226-236.

Schrader, S., Rogasik, H., Onasch, I. and Jegou, D. 2007. Assessment of soil structural differentiation around earthworm burrows by means of X-ray computed tomography and scanning electron microscopy. Geoderma., 137: 378-387.

Torsvik, V. and Ovreas, L. 2002. Microbial diversity and function in soil: from genes to ecosystems. Curr Opin Microbiol., 5: 240-245.

Van Coller-Myburgh, C., van Rensburg, L. and Maboeta, M. 2015. Assessing the ecotoxicity of gold mine tailings utilizing earthworm and microbial assays. Water Air Soil Poll, 226(7): 226-218.

Van Hook, R.I. 1974. Cadmium, lead and zinc distributions between earthworms and soils: potentials for biological accumulation. Bull Environ Contam Toxicol., 2: 509-512.

\section{How to cite this article:}

Shefali, R.K. Gupta and Dharambir Singh. 2018. Study to Enumerate the Alterations in Gut Bacterial Population of Eudrilus eugeniae Exposed to Sodium Arsenate. Int.J.Curr.Microbiol.App.Sci. 7(03): 596-600. doi: https://doi.org/10.20546/ijcmas.2018.703.070 